\title{
A fly over the barriers of communication
}

\author{
Bianca Teodorescu ${ }^{1, *}$, Mihaela-Gabriela Păun ${ }^{2}$ \\ ${ }^{1}$ University of Craiova, 13 A. I. Cuza Street, Craiova, 200585, Romania \\ ${ }^{2}$ School no 1, Balș, Romania \\ *E-mail address: m68strechie@yahoo.com
}

\begin{abstract}
Communication has a number of features: unites people to send messages. In the process of communication exists different types of communication based on verbal and non-verbal actions. The process of communication occurs in a psychological, social, cultural and physical space. Another important feature about this process, is that the communication is characterized also through dynamism; it consists in the evolution and change of persons that are involved. The quality and quantity of the information theoretical substantiate the value. Any classification of the information is based on two existing forms: scale and complexity. The structure of communication and information is defined in theories and is redefined through analogy and generalization in science. Knowledge the object of communication means to understand how the process of communication is released.
\end{abstract}

Keywords: communication; process; system of communication

\section{INTRODUCTION}

The art to communicate represents a natural process or ability with whom we are born. We learn how to communicate. Any communication implies creation and change of meanings. For a person to understand the others, it is important to know that in this process of communication the meanings are represented by the signals and codes. The observation and understanding the process of communication has the role to make us capable to communicate. Our behavior and body language can divert our actions of the others; relations are formed through a cognitive inadequacy. The partners of communication attend to attached by the way they interact and in this case, a modification in their relation will not change easily. Thus, the relations can be modified. In a group, if a person is quiet and looks lost, he communicates us that he does not want to talk with anybody. In this situation we find a change of communication, even if it is not intentional.

A communication act is not limited just to transmit the information; it also persuades the behaviors in the human relations. In the communication process is important to have an index for the past and an order for the future. Through the index, the message is sending information or content and through the order is designating the relation between partners based on the continuity of the interaction which is formed from sequences. In a communication process, switching off the ignition produce a faulty boundary sequence without losing the concentration and interest. The communicative relation implies the situation of communication; the relation is fundamentally determined by the elements of sequences. 


\section{MATERIALS OF COMMUNICATION}

People communicate through two big categories of signs: digital signs (words) with a precise code and analogical signs (gestures, postures, nonverbal languages) and without a code. In this case, it results that people communicate both digital and analogical (Craig, 1999; Berger, Riloff \& Ewoldsen, 2009). The nonverbal communication or analogical are composed by mimicry (facial expression), proxemics and gestures. If the verbal communication (digital) is aware produced, the nonverbal communication is represented by our emotional mechanism. The first language is improper to the relation and the other is adequate.

Communication relation represents a force of relation. It has a different reaction from a person to others; the reactions lead to consolidate or to modify the relation. The term "information" can be seen as a collection of dates and facts organized to reach value to the effects of their actions. But for information to have value, it must be easily accessible, complete, economical, flexible, precise, relevant and verifiable (Little john \& Foss, 2009; Littlejohn \& Foss, 2010; Borowski, 2014). The quality of information is determined by its characteristics. Any process of communication can obtain the communication as a product, but it can't be the result; it is formed by information, which represents the message between broadcaster and receiver through a channel. Communication is a social, complex and psychological phenomenon.

Our need to communicate represents a necessity in the social life in which we live. The need of communication is one of the major things that we heard everywhere we go. But what it is? We can say that it is, in fact, a selection. We take the information from the messages to make a choice in our life, but also we find to communicate in the need of novelty or from an inner impulse (Borowski, 2013; Borowski, 2014). The need to communicate is an automatic manifestation of intelligence. If the communication will not exist, our social life will be nonexistent.

In the last decade, the feelings of scepticism, distrust or even fear of the dissemination system of the information had concern increased. The mass communication denies the vital function in the democracy: information is an essential part of the society.

A permanent diversification of broadcast sources leads to manipulation in precise and identifiable codes only to the professionals. Some analysts believe that manipulation can substitute the physical violence though a symbolic one and it contributes to the effective suppression (Dima \& Vlăduțescu, 2012; Vlăduțescu \& Ciupercă, 2013).

Communication represents the most important element of a human community to optimally function. The change of the messge generates some point of view and action in manner to harmonize the knowledge about the society's purposes. Beside this, communication is seen as understanding the received messages from the various channels of communication. The concept of communication is equal with all what a community means: groups of people and social system, it has the role to implement the notion of participation. Also, communication can be seen as a process which implies the participation of the group's member; it represents a process of information transfer.

Communication is characterized through dynamism, evolution, initiative in the process (Vlăduțescu, 2013; Vlăduțescu, 2014). This communicational process is irreversible.

The efficiency of the message transfer in the communication process can be disrupted by the communication barriers. The communicationl barriers appear when the person that received the message does not understand it and misinterprets it. The purpose of the communication study is to decrease the causes that determines this type of phenomena. Barries can appears on any system of communication, this means that the sent messages is not always the received one. 
These barriers are classified in: environmental barriers, language, concepts and some of them are determined by the position in which we find the broadcaster and the receiver.

The language barriers are represented by some rules:

- for different persons, the same words can have different significations

- there exist different type of preparation and experience between the person who is talking and the other who is listening

- the receiver can sustain a strong emotion from what he hears

- the receptivity is influenced by preconceptions idea and routine

- the appearance of confused expressions and words

Environmental barriers consist in:

- improper work in a sound polluted environment

- inadequate information support

In communication, the broadcaster and receiver position can have barriers because of some certain reasons: the image about them, the way they are communicating, the feelings and intentions of the persons in the communication.

Conceptual barriers are the last category and are defined by the assumptions: the broadcaster sends hardly the message, the receiver has a lack of interest about the subject and the routine in the process of communication affects both of the partners.

Thus, these communication barriers represent real problems in the process of communication, they can be avoided through: a right plan of communication, the purpose of communication being well defined, communication has to be in the right moment, the ideas to be planned and to use an adequate language(Smarandache \& Vlăduțescu, 2014).

A person is included in two processes in which he acts as a consumer of some certain material values and activates as an information accumulator. The second process is not less important than the first because the information is not an optional clue, it is one of the fundamental condition of social life (Miege, 1995; Coman, 1999). The exemplary position of the information in the strategy of world domination is explained through its roles in the formation and science and technique development. Information progressively consolidated his sovereignty for answer the life's problems: the nature of the universe, the reality, the relations between present and future and between significations and meaning. Today, the information holds an important role in many disciplines; information science follows to solve the main problems, to discover the way in which the information is formed, the principles after it works. The evolution's forms analysis are not secondary objects in the theory of communication, they have a strong base in another systematic sciences, based on the idea that the information is a structured system, a process and the same the result of the process in construction (Dance \& Larson, 1985; Pânișoară, 2004; Tomasello, 2008).

This system is according to some structural principles to make the component parts of the information more a result of a functional interaction between producer and consumer. For an information to have power, it must create respect. In our days, the power belongs to the information and it requires a science. The words must lead by the science, not by the theory. An informed man is a powerful man. An informed society is a free and open society, where the information means democracy. A democratic society is strong, stable and consolidated. We can say that the information is a force. The measure of any force is once given by the domination. If someone will have this power to dominate, he will not hesitate to use it and if someone will control it, he can rule the world. Communication network represents an essential part in the information process. Increasing the capacity of information producers's providing implies a larger level of competence and performance in using the informational techniques and even multiplying the category of informational consumer (Craig, 2014; 
Gasderell, 2014). If a person is obligated to enter into the informational circuit, it means that he is easily manipulated. In this situation, the internet represents a paradigm that monopolizes our society's force, finance, commerce and telecommunications. The positive impact of information comes from communication: to take decision for to dominate a centre it means to offer and consume information before communicate. Manipulation is a method that is used very often in our society.

Dates represent objective facts about a process or an event which has a reduced utility if they are not transformed into information, for example: the cost, the speed and the capacity are quantitative dates.

The dates can be transformed in information through five types of process:

- condensation-dates are synthesized in a concise form and details are eliminated

- contextualization- the purpose or the reason of dates's collection are known from the begining

- calculation- dates are processed for offering useful information

- categorization- is a process that assigning the dates on category

- correction - is a process which purpose is to remove the errors.

We must know the distinction between dates, information and knowledge. Dates are defined by three elements: an identifier, attributes and value, information are a message with a new character and knowledge represents in fact simple information that we gain in time on the real world (Knapp, Hall, Horgan, 2013; Gîfu \& Teodorescu, 2014).

The culture of information is defined as an ability to localize, evaluate and use the necessary information (Stacks \& Salwen, 2014). It is a product of informational society, also the key to lifelong learning and has a major in higher education. In our century, the culture of information became a digital one and is represented by the many available information on the internet with easy access. We can say that people in 2014 are addicted to this culture. The internet is an ability to survive in XXI century.

\section{CONCLUSIONS}

Verbal communication is used as a code in our language. This code represents the most sophisticated signification system used by the member of a society. With the help of the words and operating rules is creating communication which helps the development of the human intellect. The verbal communication can be written and oral. By refusing to inform, we make the information insufficient and incomplete. The essential function in communication is to make possible the existence of a person in a community, but also the existence of the community itself; in this situation the communication represents an instinctual expression, but also an expression of thought as a human being's defining feature.

\section{References}

[1] R. T. Craig, Communication theory 9(2) (1999) 119-161.

[2] C. R. Berger, M. E. Roloff, D. R. Ewoldsen (Eds.). (2009). The handbook of communication science. Sage publications.

[3] Andrzej Borowski, International Letters of Social and Humanistic Sciences 14 (2014) 7-17. 
[4] S. W. Littlejohn, K. A. Foss (2010). Theories of human communication. Waveland Press.

[5] S. W. Littlejohn, K. A. Foss (Eds.). (2009). Encyclopedia of communication theory, Vol. 1. Sage.

[6] B. Miège (1995). La pensée communicationnelle. Grenoble: Presses universitaires de Grenoble.

[7] M. Coman (1999). Introducere în sistemul mass-media. Polirom.

[8] Andrzej Borowski, International Letters of Social and Humanistic Sciences 14 (2014) $33-41$.

[9] Florentin Smarandache, Ştefan Vlăduţescu (2014). Communication Neutrosophic Routes. Columbus, OH: Educational Publishing.

[10] Andrzej Borowski, International Letters of Social and Humanistic Sciences 4 (2013) 70-74.

[11] Ioan Constantin Dima, Ştefan Vlăduţescu (2012). Persuasion elements used in logistical negotiation: Persuasive logistical negotiation. Saarbrucken: LAP Lambert Academic Publishing.

[12] I. O. Pânişoară (2004). Comunicarea eficientă. Metode de interac iune educa ională. Iaşi: Edit. Polirom.

[13] Ştefan Vlăduţescu (2013). What Kind of Communication Is Philosophy. Jokull.

[14] F. E. Dance, C. Larson (1985). The functions of human communication. Information and behavior.

[15] Andrezj Borowski, International Letters of Social and Humanistic Sciences 2 (2014) 110-121.

[16] Florentin Smarandache, Ştefan Vlăduţescu (2014). Neutrosophic Emergences and Incidences in communication and information. Saarbrucken: LAP Lambert Academic Publishing.

[17] Ioan Constantin Dima, Mirela Teodorescu, Daniela Gifu, International Letters of Social and Humanistic Sciences 20 (2014) 46-55

[18] M. Tomasello (2008). Origins of human communication. Cambridge: MIT press.

[19] F. E. Dance (1970). The “concept” of communication. Journal.

[20] G. Rajović, J. Bulatović, International Letters of Social and Humanistic Sciences 6 (2013) 24-35.

[21] Andrezj Borowski, International Letters of Social and Humanistic Sciences 3 (2013) 69-74.

[22] Ş. Vlăduţescu, E. M. Ciupercă (2013). Next Flood Level of Communication: Social Networks. Aachen: Shaker Verlag.

[23] Daniela Gîfu, Mirela Teodorescu, International Letters of Social and Humanistic Sciences 18 (2014) 34-38.

[24] A. Borowski, International Letters of Social and Humanistic Sciences 11 (2014) 1-168. 
[25] Ștefan Vlăduțescu (2013). Principle of the Irrepressible Emergence of the Message. Jokull.

[26] Watzlawick, P., Bavelas, J. B., \& Jackson, D. D. (2011). Pragmatics of human communication: A study of interactional patterns, pathologies and paradoxes. WW Norton \& Company.

[27] Ștefan Vlăduțescu, International Letters of Social and Humanistic Sciences 10 (2014) $100-106$.

[28] D. W. Stacks, M. B. Salwen (Eds.). (2014). An integrated approach to communication theory and research. Routledge.

[29] Ștefan Vlăduțescu, International Letters of Social and Humanistic Sciences 27 (2014) 34-40.

[30] Colhon M. (2013). Automatic Lexical Alignment between Syntactically Weak Related Languages. Application for English and Romanian. In Computational Collective Intelligence. Technologies and Applications (pp. 266-275). Springer Berlin Heidelberg.

[31] Janusz Grabara, Michal Kolcun, Sebastian Kot, International Journal of Education and Research 2(2) (2014).

[32] Ştefan Vlăduţescu, Journal of Studies in Social Sciences 8(2) (2014).

[33] Knapp M., Hal J., Horgan T. (2013). Nonverbal communication in human interaction. Cengage Learning.

[34] Max G. Craig, Journal of Studies in Social Sciences 8(1) (2014).

[35] Jason L. Powell, International Letters of Social and Humanistic Sciences 7 (2014) 22-30

[36] M. G. Mangra, E. A. Cotoc, A. Traistaru (2013). Sustainable Economic Development Through Environmental Management Systems Implementation. Journal.

[37] Ştefan Vlăduţescu, American International Journal of Contemporary Research 3(10) (2013).

[38] Ștefan Vlăduțescu, International Letters of Social and Humanistic Sciences 23 (2014) 71-80.

[39] Tomáš Hes, Alena Neradová, Karel Srnec, International Letters of Social and Humanistic Sciences 7 (2013) 55-75.

[40] Vlăduţescu Şt. (2004). Hipoacuzia şi surditatea ca boli profesionale. Sitech Publishing House, Craiova.

[41] Ştefan Vlăduţescu, European Scientific Journal 9(32) (2013).

[42] Camelia Manolescu. (1997). Le trust en droit anglais. (Doctoral dissertation). 
[43] Aurelia Traistaru (2013). Consolidation of the green marketing profile in current austerity period. Jokull.

[44] J. H. Gasderell, International Letters of Social and Humanistic Science 22 (2014) 85-91.

[45] Jason L. Powell, International Letters of Social and Humanistic Sciences 16(2) (2014) 132-143.

( Received 02 September 2014; accepted 09 September 2014 ) 